Biol. Stud. 2013: 7(3); 67-76 • DOI: https://doi.org/10.30970/sbi.0703.309

www.http://publications.Inu.edu.ua/journals/index.php/biology

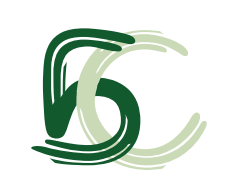

UDC: 631.528.6:633.34:612.465.355.4115

\title{
STRUCTURE OF INTERNALS TISSUES OF FIRST GENERATION OF RATS FED BY NATURAL AND TRANSGENIC SOYBEAN
}

\author{
O. Dolaychuk, R. Fedoruk \\ Institute of Animal Biology of UAAS of Ukraine, 38, V. Stus St., Lviv 79034, Ukraine \\ e-mail:Dolaychuk@gmail.com
}

\begin{abstract}
Studied of macro- and microstructure of kidney, liver and spleen of female and male rats did not show significant deviations from such structures of the control group. It has been found that structure of spleen follicles of female and male control groups of rat is better expressed comparing to those whose diet included soybean. The animals whose diet included both conventional and transgenic soybean were found to have a slight increase of Bowman's capsule in kidney tissues enabled by glomerulus reduction that is apparently due to the effect of both soybean varieties of biologically active components on water-salt metabolism in animals. Considering that the internal structure was preserved and conformed with the norms for animals of given species and age in both control and experimental female and male rat groups, a conclusion on the absence of significant negative or positive effect of GM soybean components on the histological structure of liver, spleen and kidneys can be proposed.
\end{abstract}

Keywords: genetically modified soybean, histology of internals, liver, spleen, kidney.

\section{INTRODUCTION}

During recent years there is a widespread use of transgenic plants characterized by high resistance to herbicides, pathogenic agents or insect pests, although the question of the safety of their influence on human or animal body unclear remains opened $[1,2]$. A significant part of transgenic soybean contains insertions of gene responsible for the expression of glyphosate-tolerant enzyme, 5-enolpyruvylshikimat-3-phosphate synthase (EPSPS), which in its turn was CP4 strain isolated from Agrobacterium tumifaciens bacteria and, with the use of biolistic method, inserted in the genome of A5403 soybean line [3]. This modification makes plants resistant to glyphosate, an active ingredient of the most common Roundup herbicide. A number of studies have been focused on agronomic characteristics, chemical composition and nutritional value of GM soybean research, as soybean and its derivative products are the best source of protein in the diet of many farm animals [4-6]. Literature contains the results of GM soybean feeding studies conducted on various animal species, including rats, pigs, poultry, cattle and fish 
[7-10]. However, a number of publications on long-term research conducted on a few generations of animals is limited. A transmissibility of transgenic DNA from GM crops to animal organisms, as well as direct effect of toxic and allergenic transgenic proteins, pleiotropic effect on plant metabolism, possible accumulation of herbicides and metabolites in resistant varieties and types of agricultural plants points out a necessity of long-term experiments. Other studies have shown that the DNA fragments obtained from plant chloroplast genes are integrated into the immune cells of rodents [11], and are also found in skeletal muscles, blood, liver, spleen and kidneys [12]. It is also found that kidney and liver are the most vulnerable to the effect of transgenic food, modified in resistance to herbicides. In particular, it was found that some varieties of GM maize (NK 603, MON 810, MON 863) are characterized by hepatorenal toxicity, associated with possible accumulation of herbicides [13-15]. This points out a necessity for further studying of internals histological structure during a long-term feeding of glyphosatetolerant GM plants varieties. Thus, an objective of our work was to study the effect of conventional and GM soybean feeding on growth and microstructure of the internal organs (liver, spleen and kidney) of the first generation of female and male rats.

\section{MATERIALS AND METHODS}

Genetically modified soybean line GTS 40-3-2 ("Monsanto Canada Inc.") was used. Line GTS 40-3-2 soybean resistant to herbicides containing glyphosate was used. A development of GTS 40-3-2 was based on recombinant DNA technology, through introduction of a glyphosate tolerant form of the enzyme 5-enolpyruvylshikimate-3-phosphate synthase (EPSPS) gene isolated from Agrobacterium tumefaciens strain CP4, into the commercial soybean variety "A5403" [3]. Also, we used a traditional domestically soybean variety Chernivecka 9 which was not genetically modified. According to literature data soybean variety Chernivecka 9 of chemical, fatty acid and aminoacid composition compositionally were equivalent to genetically modified glyphosate-resistant varieties soybean line GTS 40-3-2 [16].

The research was conducted in vivarium of the Institute of Animal Biology of UAAS on 6 groups of rats, 6 rats of similar age (3 months), body weight (120-140 g) and housing conditions in each group. Rats of I (female) and IV (male) control groups were fed by standard balanced diet along with feeding granulated all-mash throughout the study period. The experimental group of animals were fed with diet according to the control group scheme with the replacement of $30 \%$ of all-mash nutrition with conventional soybean (II female and V male rat groups) and transgenic soybean (III female and VI male rat groups), respectively. Before feeding, the soybeans were subjected to heat treatment for 2 hours at $140^{\circ} \mathrm{C}$ to destroy the antinutrients. The diet of lach group met standard requirements and established norms. Sixty days following the start of soybean feeding, the decapitation of animals was carried for physiological and histological studies. The euthanasia was carried out with the use of light ether anesthesia, with out violations of humane treatment of laboratory animals' norms, with regard to the accepted bioethical norms and compliance with the international regulations regarding vertebrate animal experiments [17].

The samples of $0.3-0.5 \mathrm{~cm}$ in size from the left hepatic lobe (lobus hepatis sin.), the cranial part of the spleen (splen margo cran.) and the bulging lateral border of kidney (ren margo lat.) on the boundary between the cortex and medulla were taken for histological examination. The samples were fixed in $10 \%$ formalin solution and embedded

ISSN 1996-4536 • Біологічні Студії / Studia Biologica • 2013 • Том 7/№3 • C. 67-76 
into paraffin according to standard procedures [18]. The sections of 7 micron in size together with the sections carrier system were produced on HM 340E microtome, and stained with hematoxylin and eosin. The morphological studies were performed with the use of histologic specimen visual analysis system. The histologic sections were pictured with optical microscope built-in camera equipped with image freezing function by Med. Cam application software package.

\section{RESULTS AND DISCUSSION}

Macroscopic examination of liver has shown that its structure is preserved both in female and male control and research groups. The organ is typically dark cherry, with rounded edges, and covered with connective-tissue capsule. The organ's distinction is a poor growth of interlobular connective tissue featuring rats. In the lobule center there is a central vein from which the hepatic plates radiate, formed by two rows of hepatocytes of cubic or polygonal shape featuring all animal groups (Fig. 1 and 2). The hepatocytes were characterized microscopically by having a slightly granular cytoplasm of pink-red color with clearly visible round nucleus. The parenchyma contains single hepatocytes regeneration areas in the form of dual cells. Central and portal vein openings are moderately plethoric. The histological sections of liver of control and experimental group animals revealed neither vacuolization, nor lipid infiltration of hepatocytes. However, the minor disturbances in the beam-like structure of hepatocytes (Fig. 1) were observed in liver of female rats (F1). As illustrated in the Figures, the cytoplasm makes a clear line of liver cells and has a basophilic shade. Other researches conducted on young (2-8 months) and adult (24 months) mice fed with GM soybean revealed some hepatocyte nuclei modifications due to transcription/splicing disturbances, as well as some morphofunctional changes in mitochondria $[19,20]$. The cause of changes is not fully established, but it should be mentioned that replacing of GM soybean with the traditional analogue soybean induced the hepatocyte nuclei structure to recover [20]. Histological studies involving pest resistant GM maize did not show evident liver tissues structure changes [15]. Obviously, the GM negative impact concerning genetic modification which enables plant herbicide resistance is caused by the same herbicides impact. This is proved by an increased density of lysosomes, as well as by changes in structure of hepatocyte mitochondrial membranes.

Similar results were obtained by Sakamoto, Y. et al. $(2007,2008)$ after studying a short- and long-term influence of conventional and transgenic soybean feeding on liver histologic structure of rats. The data indicate an absence of significant changes in liver microstructure involving conventional and GM soybean in the diet [21, 22]. Similar results of liver histological studies of mice and rats fed with transgenic glyphosate herbicide resistant soybean were obtained [19, 23-25], which indicate its equivalence with other varieties. Differences in liver microstructure in case of GM herbicide resistant soybean feeding are associated with possible glyphosate accumulation in soybean. Particularly, research conducted by Malatesta, M. has shown that glyphosate herbicide resistant soybean feeding led to reduction of metabolic rate and hepatocyte mitochondrial respiration $[19,23]$. That was proved by an increased density of lysosomes, and by changes in hepatocyte mitochondrial membranes.

It was shown that spleen morphological structure in female and male rats fed with conventional and transgenic soybean did not lead to deviations from the control group. Histological sections of rat spleen tissue of control and experimental groups clearly 
reveal a thin connective tissue capsule with no visible thickening (Fig. 3, a and 4, a). Splenic parenchyma is composed of white and red pulp; their ratio is visually identical in control and experimental groups (Fig. 3 and 4). A red pulp contains equally spaced white pulp tissue in the form of lymph nodes around central veins and elongated lymphoid clusters adjacent to the arterial adventitia. Red pulp matrix is formed by reticular tissue comprising macrophages, granular and non-granular leukocytes, single megakaryocytes, and erythrocytes. White pulp is formed by lymphoid tissue producing lymphocytes. The follicles have following zones: periarterial zone, germinal center, mantle and marginal zones. Typically, the follicle structure of spleen in control group rat is better clearly expressed than spleen structure of animals fed with diet including soybean, both for females and males. However, the number and size of lymph follicles in experimental group rat spleens coincide with those in control group (Fig. 3, b and 4,b). No significant changes in the histological structure in spleens of experimental group of rats compared to control one indicates a physiological level of lymphocytes reactivity in rat spleen under the influence of both conventional and transgenic soybean components.
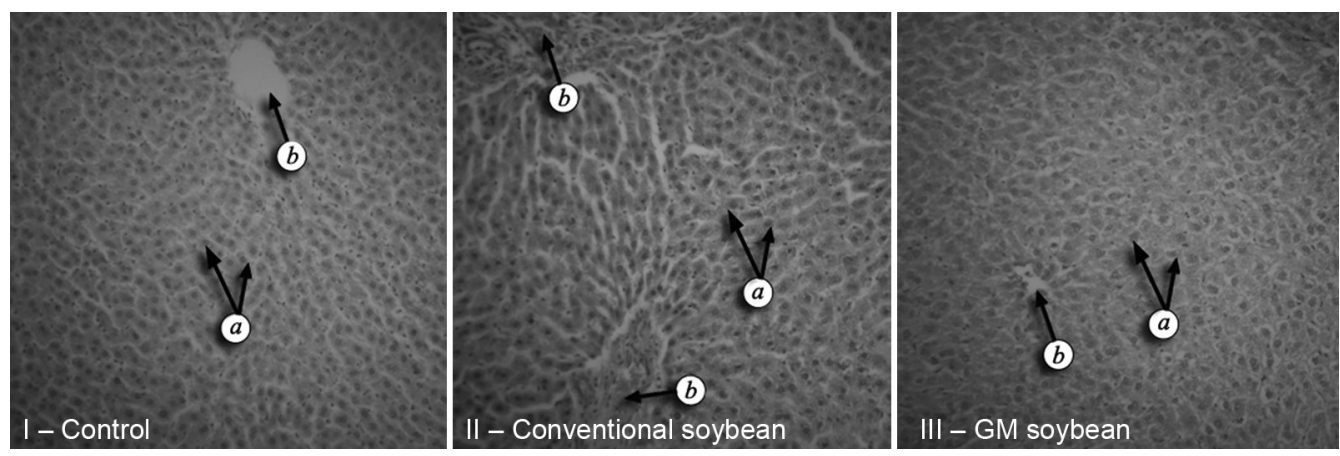

Fig. 1. Normal microstructure of liver in I and II group F1 female rats. Disturbances in beam-like structure of liver in III group rats. Hematoxylin and eosin. 10× ocular, 200× objective; ( $a$ - hepatocytes; $b$ - vessel opening)

Рис. 1. Нормальна мікроструктура печінки самок щурів F1 I та II груп. Порушення балкової структури печінки щурів III групи. Гематоксилін та еозин. Ок. 10, об. 200; (


Fig. 2. Normal microstructure of F1 male rat liver. Hematoxylin and eosin. 10× ocular, 200× objective; (a hepatocytes; $b$ - vessel opening)

Рис. 2. Нормальна мікроструктура печінки самців щурів F1. Гематоксилін та еозин. Ок. 10, об. 200; (а гепатоцити, $b$ - просвіти судин)

ISSN 1996-4536 • Біологічні Студії / Studia Biologica • 2013 • Том 7/№3 • С. 67-76 

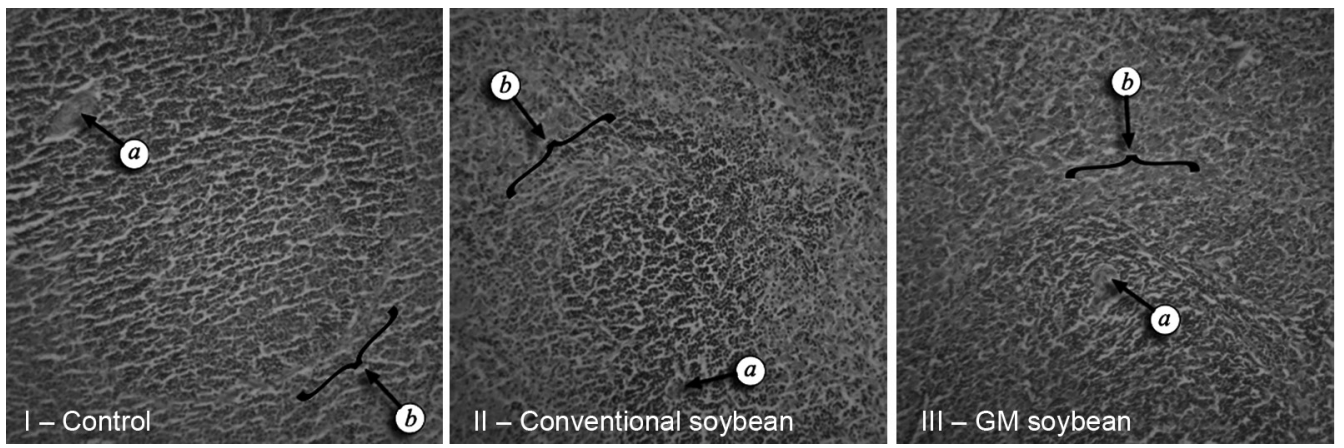

Fig. 3. Normal microstructure of F1 female rat liver. Hematoxylin and eosin. 10× ocular, 200× objective; (a vessel opening; $b$ - lymphatic follicle)

Рис. 3. Нормальна мікроструктура селезінки самок щурів F1. Гематоксилін та еозин. Ок. 10, об. 200; (a - просвіт судини; $b$ - лімфатичний фолікул)
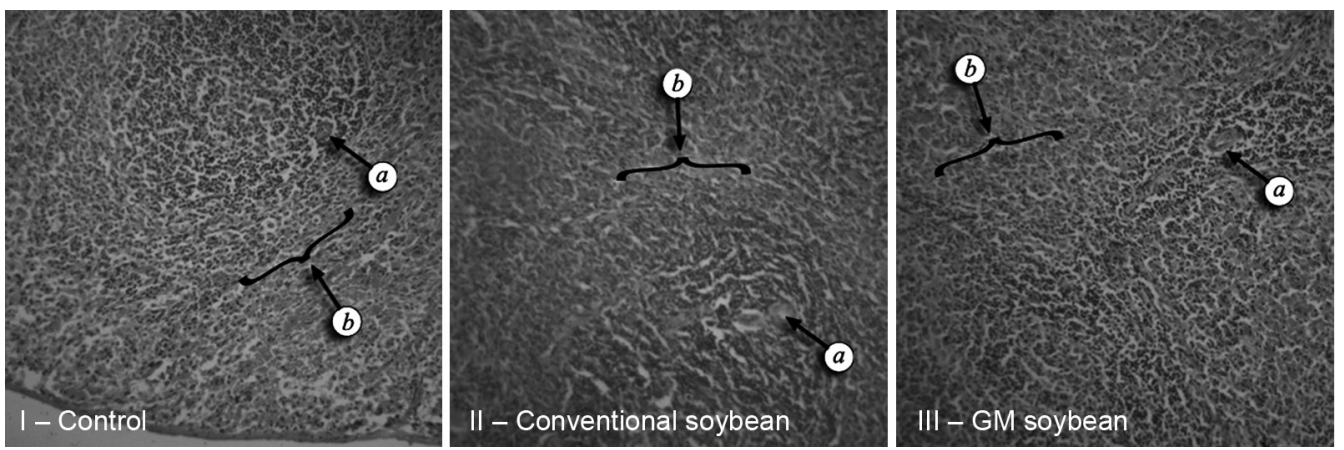

Fig. 4. Normal microstructure of F1 male rat liver. Hematoxylin and eosin. 10× ocular, 200× objective; (a vessel opening; $b$ - lymphatic follicle)

Рис. 4. Нормальна будова селезінки самців щурів F1. Гематоксилін та еозин. Ок. 10, об. 200; (a - просвіт судини; $b$ - лімфатичний фолікул)

The obtained results also confirm a the results of other scientists studying rats and mice fed on conventional and transgenic soybean in 30\% amount from standard diet for 15 weeks. The researchers point out the absence of histological differences in the structure of immune system organs, i.e. the spleen, thymus, mesenteric lymph nodes and Peyer's glands [26]. The absence of potential changes in the spleen structure is also proved by a number of studies conducted in rats and mice involving different duration of transgenic and conventional soybean feeding [21, 22, 25]

There are studieds of functional status and histology of single organs, including spleen, conducted on different generations of animals. Recent data are limited, in particular, internals histologic examination carried on two generations of sheep fed on GM maize [27], the research aimed at identifying transgenic DNA fragments in internals tissues conducted on five generations of mice fed on GM triticale [28] evaluation of enzyme strength in spleen tissues of two generations of goats fed on transgenic soybean [29]. The results of those studies indicated no significant effect of ingredients of GM plants feed on the internal structures and their functions well as activity of the studied enzymes. 
The effect of alimentary factors is strongly influnced by urinary system, studied microstructurally, particularly on the kidneys level. It was found that kidney and liver are most easily affected by transgenic feed modified in resistance to herbicides. In particular, it was proved that some GM maize varieties (NK 603, MON 810, MON 863) are marked by a hepatorenal toxicity associated with possible accumulation of herbicides [13-15]. Similar data were obtained in the study of kidney histology in broiler chicken fed with GM soybean in the amount of 75 and $100 \%$ from the diet [30]

The microscopic structure of kidney was conduit in each animal group. The organ was of firm texture and typical color. The analysis of kidney microstructure in control and experimental group males and females (F1) indicates a distinct capsule, cortex and medulla. The cortex contains numerous clearly distinguished nephron glomerulus of spherical shape and a slightly rough surface (Fig. $5, b$ and $6, b$ ). The glomerulused are enclosed in the Bowman's capsules with lumen of falciform or surrounding the glomerulus in the ring form (Fig. 5, a and 6, a). Capsule cavities are content free. The space between the glomeruluses consists of numerous rounded sections of tubules and cortex vessels. Tubular epithelium is firmly against basement membrane surface. There are visible proximal and distal kidney tubules with typical structure between renal corpuscle of each animal group. Straight tubules in medulla substance and collector tubules have no changes in the experimental group females and males compared to control ones.
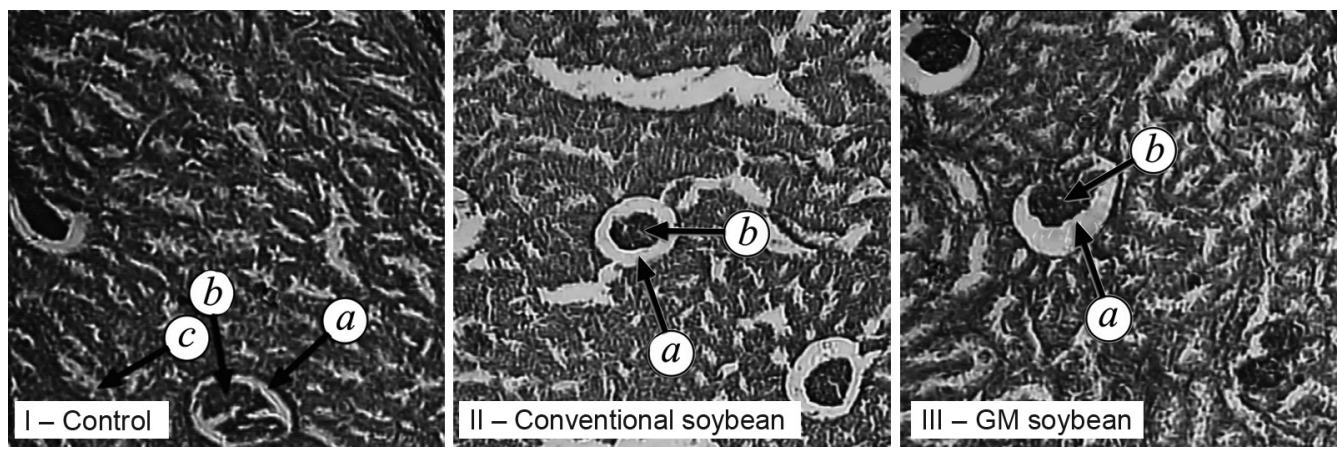

Fig. 5. Normal microstructure of control group F1 female rat kidney. Increased Bowman's capsule lumen in I and III group F1 female rat kidney. Hematoxylin and eosin. 10x ocular, 200x objective; (a - Bowman's capsule; $b$ - vascular glomerulus; $c$ - vessel opening)

Рис. 5. Нормальна мікроструктура нирок самок щурів F1 контрольної групи. Збільшення просвіту капсули Шумлянського-Боумена нирок самок щурів F1 II і III груп. Гематоксилін та еозин. Ок. 10, об. 200; (а - капсула Шумлянського-Боумена; $b$ - судинний клубочок; $c$ - скупчення еритроцитів у просвіті судини)

Kidney tissues of females of the first generation have slightly increased lumen of Bowman's capsule. Taking into consideration that similar histological changes occurred in kidney tissues of animals fed wiht both conventional and GM soybean, this obviously was not caused by genetic modification but rather by a particular effect of soybean components on water-salt metabolism. Reduced diameter and volume of vascular glomerulus indicates a decline of renal function in experimental groups. Similar changes of the Bowman's capsule lumen were also identified in kidney tissue specimen of male rats (F1) - the lumen is slightly increased due to reduction of vascular glomerulus. One of the most important kidney processes is the excretion of toxic metabolic waste products

ISSN 1996-4536 • Біологічні Студії / Studia Biologica • 2013 • Том 7/№3 • С. 67-76 

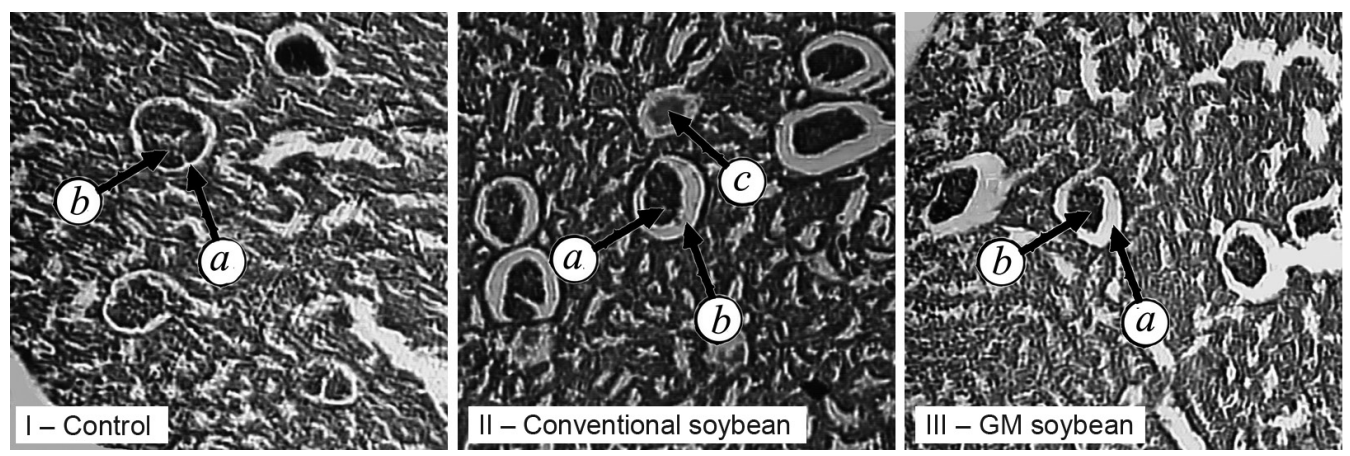

Fig. 6. Normal microstructure of control group F1 male rat kidney. Increased Bowman's capsule lumen of F1 male rat kidney. Hematoxylin and eosin. 10× ocular, $200 \times$ objective; ( $a$ - Bowman's capsule; $b-$ vascular glomerulus; $c$ - vessel opening)

Рис. 6. Нормальна мікроструктура нирок самців щурів F1 контрольної групи. Збільшення просвіту капсули Шумлянського-Боумена нирок самців щурів F1. Гематоксилін та еозин. Ок. 10, об. 200; (a - капсула Шумлянського-Боумена; $b$ - судинний клубочок; $c$ - скупчення еритроцитів у просвіті судини)

by filtration in the glomeruluses and tubules. Therefore, such changes in the Bowman's capsule lumen may suggest changes in organ functioning. The results indicate no significant disfunction in histological structure of kidney bringing them into line with the literature data of other authors [24, 26, 31].

\section{CONCLUSION}

Summarizing, it was confirmed that the morphological and histological study of the internals organs of the first generation females and males did not reveal significant differences between control and experimental groups. It was found that spleen follicle structure in female and male rats of control groups is better expressed comparing to animals fed with diet including soybean. The experimental group animals had a slight increase of the Bowman's capsule lumen in kidney tissues due to a reduction of vascular glomerulus, obviously caused by the influence of biologically active components of both soybean varieties on water-salt metabolism in animal. Considering that both female and male rat tissue structure of control and experimental groups, fed with diet including conventional and transgenic soybean, was retained and conformed with the norms for animals of the given species and age, we conclude that there is no clear negative or positive impact of GM soybean components on the histological structure of liver tissue, spleen and kidney.

1. Flachowsky G., Chesson A., Aulrich K. Animal nutrition with feeds from genetically modified plants. Arch. Anim. Nutr, 2005; 59(1): 1-40.

2. European Food Safety Authority (EFSA) GMO Panel Working Group on Animal Feeding Trials. Safety and nutritional assessment of GM plants and derived food and feed: The role of animal feeding trials. Food Chemistry and Toxicology, 2008; 46: 2-70.

3. Патрушев М. В. Возняк М. В. Генетически модифицированные источники: характеристика некоторых ГМ-линий, их детекция. Партнеры и конкуренты, 2004; 10: 19-26.

4. Taylor N.B., Kishore G.M. Development, identification, and characterization of a glyphosatetolerant soybean line. Crop Sci, 1995; 35: 1451-1461. 
5. Astwood J.D., Leach J.N., Fuchs R.L. Stability of food allergens to digestion in vitro. Nature Biotechn, 1996; 14: 1269-1273.

6. Nelson K.A. Renner K.A. Weed management in wide- and narrow-row glyphosate-resistant soybean. J. Prod. Agric, 1999; 12: 460-465.

7. Aumaitrea A., Aulrichb K., Chesson A. et al. New feeds fromgenetically modified plants: Substantial equivalence, nutritional equivalence, digestibility and safety for animals and the food chain. Lives.t Prod. Sci, 2002; 74: 223-228.

8. Aumaitre A., Aulrich K., Chesson A. et al. Soybean meal from roundup ready or conventional soybeans in diets for growing-finishing swine. J. Anim. Sci, 2002; 80: 708-715.

9. Cromwell G. L., Lindemman M. D., Randolph, J.H. et al. Soybean meal from roundup ready or conventional soybeans in diets for growing-finishing swine. J. Anim. Sci, 2002; 80(3):708-15.

10. Faust M.A. New feeds from genetically modified plants: The US approach to safety for animals and the food chain. Livest. Prod. Sci, 2002; 74: 239-254.

11. Schubbert R., Renz D., Schmitz B. et al. Foreign (M13) DNA ingested by mice reaches peripheral leukocytes, spleen, and liver via the intestinal wall mucosa and can be covalently linked to mouse DNA. Proc. Natl. Acad. Sci. USA, 1997; 94: 961-966.

12. Tony M. A., Butschke A., Broll H. et al. Safety assessment of BT 176maize in broiler nutrition: Degradation of maize-DNA and its metabolic fate. Arch. Anim. Nutr, 2003; 57: 235-252.

13. Spiroux J., Roullier F., Cellier D. et al. A comparison of the effects of three GM corn varieties on mammalian health. Int. J. Biol. Sci, 2009; 5:706-726.

14. Séralini G. E., Cellier D., Spiroux J. New analysis of a rat feeding study with a genetically modified maize reveals signs of hepatorenal toxicity. Arch. Environ. Contam. Toxicol, 2007; 52: 596-602.

15. Kilic A., Akay M. T. A three generation study with genetically modified Bt corn in rats: biochemical and histopathological investigation. Food Chem. Toxicol, 2008; 46: 1164-1170.

16. Параняк Р.П., Вудмаска І.В., Параняк М.P. та ін. Оцінка компоцизійної еквівалентності генетично модифікованої (GTS 40-3-2) та немодифікованої сої за амінокислотним та жирнокислотним складом. Здобутки клін. і експеримент. медицини, 2009, 1(10): 117-120.

17. European convention for the protection of vertebrate animals used for experiments and other scientific purposes. Strasbourg: Coun. of Europe, 1986. 53 p.

18. Волкова О.В. Елецкий Ю.К. Основы гистологии с гистологической техникой. М.: Медицина, 1982. 303 с.

19. Malatesta M., Caporaloni C., Gavaudan S. et al. Ultrastructural morphometrical and immunocytochemical analyses of hepatocyte nuclei from mice fed on genetically modified soybean. Cell Structure and Function, 2002; 27:173-180.

20. Malatesta M., Tiberi C., Baldelli B. et al. Reversibility of hepatocyte nuclear modifications in mice fed on genetically modified soybean. European Journal of Histochemistry, 2005; 49: 237-242.

21. Sakamoto Y., Tada Y., Fukumori N. et al. A 52-week feeding study of genetically modified soybeans in F344 rats. J. Food Hyg. Soc. Japan, 2007; 48: 41-50.

22. Sakamoto Y., Tada Y., Fukumori N. et al. A 104-week feeding study of genetically modified soybeans in F344 rats. J. Food Hyg. Soc. Japan, 2008; 49: 272-282.

23. Malatesta M., Boraldi F., Annovi G. et al. A long-term study on female mice fed on a genetically modified soybean: effects on liver ageing. Histochem. Cell Biol, 2008; 130: 967-977.

24. Appenzeller L.M., Munley S.M., Hoban D. et al. Subchronic feeding study of herbicide-tolerant soybean DP-356Ø43-5 in Sprague Dawley rats. Food Chem. Toxicol, 2008; 46: 2201-2213.

25. Delaney B., Appenzeller L.M., Munley S.M. et al. Subchronic feeding studv of high oleic acid soybeans (event DP-305423-1) in Sprague-Dawley rats. Food Chem. Toxicol, 2008; 46: 3808-3817.

26. Teshima R., Akiyama H., Okunuki $H$. et al. Effect of GM and non-GM soybeans on the immune svstem of BN rats and B10A mice. J. Food Hyg. Soc. Japan, 2000; 41: 188-193.

ISSN 1996-4536 • Біологічні Студії / Studia Biologica • 2013 • Том 7/№3 • С. 67-76 
27. Trabalza-Marinucci M., Brandi G., Rondini C. et al. A three-year longitudinal study on the effects of a diet containing genetically modified Bt176 maize on the health status and performance of sheep. Livestock Sci, 2008; 113: 178-190.

28. Baranowski A., Rosochacki S., Parada R. et al. The effect of diet containing genetically modified triticale on growth and transgenic DNA fate in selected tissues of mice. Anim. Sci. Pap. Rep, 2006; 24: 129-142.

29. Tudisco R., Mastellone V., Cutrignelli M.I. et al. Fate of transgenic DNA and evaluation of metabolic effects in goats fed genetically modified soybean and in their offsprings. Animal, 2010; 1: 1-10.

30. Cirnatu D., Jompan A., Sin A.l. et al. Multiple organ histopathological changes in broiler chickens fed on genetically modified organism. Rom. J. Morphol. Embryol, 2011; 52(1): 475-480.

31. Zhu Y., Li D., Wang F. et al. Nutritional assessment and fate of DNA of soybean meal from Roundup Ready or conventional soybeans using rats. Arch. Anim. Nutr, 2004; 58: 295-310.

\title{
СТРУКТУРА ТКАНИН ВНУТРІШНІХ ОРГАНІВ ЩУРІВ ПЕРШОГО ПОКОЛІННЯ ЗА ЗГОДОВУВАННЯ СОЇ НАТУРАЛЬНОГО І ТРАНСГЕННОГО СОРТІВ
}

\author{
О. Долайчук, P. Федорук \\ Інститут біології тварин НААН України, вул. В. Стуса, 38, Львів 79034, Україна \\ e-mail: Dolaychuk@gmail.com
}

Дослідженнями макро- і мікроструктури нирки, печінки та селезінки самок і самців щурів дослідних груп не було встановлено суттєвих відхилень від їх структури у щурів контрольної групи. Встановлено, що структура фолікулів селезінки самок і самців щурів контрольних груп більш чітко виражена, порівняно з тваринами, до раціону яких входила соя. У тварин, до раціону яких входила соя як нативного, так і трансгенного сортів, було встановлено незначне збільшення просвіту капсули Шумлянського-Боумена у тканинах нирки, за рахунок зменшення судинного клубочка, що, очевидно, зумовлено впливом біологічно активних компонентів сої обох сортів на водно-сольовий обмін організму тварин. Враховуючи, що структура органів була збережена і відповідала нормі для тварин даного виду і віку у самок та самців щурів як контрольних груп, так і дослідних, можна зробити висновок про відсутність вираженого негативного чи позитивного впливу ГМ-компонентів сої на гістологічну структуру тканин печінки, селезінки і нирки.

Ключові слова: генетично модифікована соя, гістологія внутрішніх органів, печінка, селезінка, нирка.

\section{СТРУКТУРА ТКАНЕЙ ВНУТРЕННИХ ОРГАНОВ КРЫС ПЕРВОГО ПОКОЛЕНИЯ ПРИ СКАРМЛИВАНИИ СОИ НАТУРАЛЬНОГО И ТРАНСГЕННОГО СОРТОВ}

\author{
О. Долайчук, Р. Федорук \\ Институт биологии животных НААН Украины, ул. В. Стуса, 38, Львов 79034, Украина \\ e-mail: Dolaychuk@gmail.com
}

Исследованиями макро- и микроструктуры почки, печени и селезенки самок и самцов крыс опытных групп не было установлено существенных отклонений от 
их структуры у крыс контрольной группы. Установлено, что структура фолликулов селезенки самок и самцов крыс контрольных групп более четко выражена по сравнению с таковой у животных, в рацион которых входила соя. У животных, в рацион которых входила соя как нативного, так и трансгенного сортов, было установлено незначительное увеличение просвета капсулы Шумлянского-Боумена в тканях почки, за счет уменьшения сосудистого клубочка, что, очевидно, обусловлено влиянием биологически активных компонентов сои обоих сортов на водно-солевой обмен организма животных. Учитывая, что структура органов была сохранена и соответствовала норме для животных данного вида и возраста у самок и самцов крыс как контрольных групп, так и опытных, можно сделать вывод об отсутствии выраженного отрицательного или положительного влияния ГМ-компонентов сои на гистологическую структуру тканей печени, селезенки и почки.

Ключевые слова: генетически модифицированная соя, гистология внутренних органов, печень, селезенка, почка.

Одержано: 12.07.2013 